International Journal of Environment, Agriculture and Biotechnology
Vol-6, Issue-1; Jan-Feb, 2021
Journal Home Page Available: $\underline{\text { https://ijeab.com/ }}$
Journal DOI: $10.22161 /$ ijeab

\title{
Assessment of Caecal Microbiome in two Breeds of Rabbits Fed Fermented Cocoa Podhusk Meal
}

\author{
O.B. Faluyi ${ }^{1 *}$, M. A. Olude ${ }^{2}$, M. Adegbenro ${ }^{1}$ \\ ${ }^{1}$ Department of Animal Production and Health, Federal University of Technology, Akure, Nigeria \\ ${ }^{2}$ Department of Veterinary Anatomy, College of Veterinary Medicine, Federal University of Agriculture, Abeokuta, Nigeria \\ *Corresponding Author
}

Received: 23 Nov 2020; Received in revised form: 11 Jan 2021; Accepted: 09 Feb 2021; Available online: 28 Feb 2021

(C2021 The Author(s). Published by Infogain Publication. This is an open access article under the CC BY license

(https://creativecommons.org/licenses/by/4.0/).

\begin{abstract}
The study was conducted to determine the effect of inclusion of fermented cocoa pod husk meal in feed of rabbits on the microbial flora in the caecum.Sixty 5 weeks (35 days) old grower rabbits comprising 2 breeds (thirty New Zealand White and thirty Chinchilla) were used for the study. They were randomly distributed into six treatments of 10 rabbits per group and fed diets containing fermented cocoa pod husk meal (FCPHM) at 0\%, $12.5 \%$ and $25 \%$ inclusion levels for a period of 8 weeks. Contents of the caecumof experimental rabbits were collected at the end of the feeding trial for analysis of bacterial counts/load, identification and characterization of the bacteria organisms. The results showed that the different breeds of rabbit and varying inclusion levels of FCPHM had significant influence $(P<0.05)$ on the bacterial and coliform counts in the caecum. The average caecal bacterial and coliform population increased as the inclusion levels of FCPHM increased with rabbit fed control diet having $56.88 \times 10^{2} \mathrm{cfu} / \mathrm{ml} ; 7.38 \times 10^{2} \mathrm{cfu} / \mathrm{ml}$; those fed $12.5 \%$ FCPH having $87.82 \times 10^{2} \mathrm{cfu} / \mathrm{ml} ; 10.63 \times 10^{2} \mathrm{cfu} / \mathrm{ml}$ and those fed $25 \% \mathrm{FCPHM}$ having $101.63 \times 10^{2} \mathrm{cfu} / \mathrm{ml}$; $15.25 \times 10^{2} \mathrm{cfu} / \mathrm{ml}$ bacteria and coliform counts respectively. The breed effect also showed that New Zealand White had higher bacterial and coliform counts of $93.67 \times 10^{2} \mathrm{cfu} / \mathrm{ml}$ and $13.58 \times 10^{2} \mathrm{cfu} / \mathrm{ml}$ when compared to Chinchilla with $70.58 \times 10^{2} \mathrm{cfu} / \mathrm{ml}$ and $8.56 \times 10^{2} \mathrm{cfu} / \mathrm{ml}$. Only Salmonella and Bacillus species of bacteria were commonly isolated from the rabbits fed the three dietary treatments. It can be concluded that the different breeds of rabbit and inclusion of FCPHM in their diets significantly altered the composition and population of caecal microbiota.
\end{abstract}

Keywords-Caecum, Cocoa pod husk, Microbial flora, Rabbits.

\section{INTRODUCTION}

In Nigeria presently the demand for animal protein is far higher than the supply, thus for quick increased supply of animal protein and products, it is necessary that animals with short generation intervals be reared. One of the domestic animals with short generation interval considered in this study is the domestic rabbit (Oryctolaguscuniculus).

In terms of commercial production, the rabbit excels other livestock animals like cattle, sheep and goat and ranks close to broiler chicken in terms of growth rate, feed conversion efficiency and meat quantity(Adegbolaet al., 1986). Nutritionally, rabbit meat is considered the healthiest meat option containing a higher protein $(20-21 \%)$ and lower fat content (10-11\%) when compared with meat from other species (Ajayiet al., 2007). Furthermore, Janieri (2003) had reported that rabbit meat has the cholesterol value of $169 \mathrm{mg} / 100 \mathrm{~g}$ (dry matter basis) when compared with beef (200mg), chicken (220mg), and low sodium content. Consequently, rabbit meat has been listed in United State 
Department of Agriculture (USDA) as an approved meat source for hypertensive patients.

However, as reported by Ozor and Madukwe (2005) nutrition and housing are some of the constraining factors in the adoption of improved rabbit technologies by small-scale farmers, with similar observations being made by Oseni, et al. (2008) in western Nigeria.Therefore, the resurgence of interest in rabbit production in Nigeria calls for research into alternative sources of energy and protein yielding ingredients to replace or supplement the expensive conventional cereal grains and legumes. The prices of such conventional protein and energy feed ingredients such as maize, rice, sorghum, ground nut, soybean have escalated over time that it is becoming uneconomical to use them in rabbit feed (Esonuet al., 2004; Oduguwaet al., 2004).Animal nutritionists have therefore advocated for the use of agro-industrial byproducts as unconventional feedstuffs because they are cheaper and available in large quantities in producing countries.

Several crops and their by-products have potential as possible alternatives for livestock feed industry. One such crop is cocoa, a very abundant crop in tropical regions of Africa and its by-products have been successfully used as alternative feedstuff in livestock production (Makinde et al., 2019). Cocoa pod husk, cocoa bean shell and cocoa bean meal form over $70 \%(\mathrm{w} / \mathrm{w})$ of a whole matured fruit of cocoa (Theobroma cacao L.), and these are the major agroindustrial by-products from cocoa processing industries and are usually considered as "waste" and left to rot on the cocoa plantation.

Diet plays an important role in modulating gut microbiome by providing food substrates forgut microorganisms (Conlon and Bird, 2014; Kim et al., 2015). Furthermore, several studies demonstrated that a close relationship exists between gut microfloraand health of host. The role of indigenous microorganisms includesboth a protection against pathogens (the barrier effect) and a strong implication in thedevelopment and maturation of digestive mucosa immunity. Also the maintenance of guthealth is complex and relies on a delicate balance between the mucosa (including theabsorptive epithelium and the digestive immune system), the commensal microflora andenvironmental factors including diet(Fortun-Lamothe and Boullier, 2004).

Hence this study was carried out to determine the effect of inclusion of CPH meal in diets on caecal microbiome and inadvertently the health status of two breeds of rabbits.

\section{MATERIALS AND METHOD}

\section{Experimental site}

The feeding trial of the experiment was carried out at the Livestock section (Rabbit unit) of the Teaching and Research Farm and laboratory analysis in Microbiology Laboratory of the Department of Animal Production and Health both of The Federal University of Technology, Akure, Nigeria.

\section{Collection and Fermentation of Cocoa Pod Husk}

The cocoa pod husks $(\mathrm{CPH})$ were collected from cocoa plantations in Idanre and Ondo towns, Nigeria. The pods were cleaned with sterile water, chopped, sun-dried, milled and analyzed for proximate composition. The milled cocoa pod husk (CPH) was then subjected to solid state fermentation using Rhizopusstolonifer to reduce the theobromine and fibre contents prior to its usage. The fermentation process was carried out by dissolving ten (10) grams of urea in 100 litres of water which was used to moisten the CPH meal. One litre of the prepared inoculums of the starter culture of Rhizopusstoloniferwas used to inoculate the urea treated CPH meal and kept in a tray incubating chamber to initiate the fermentation process. The fermentation of the cocoa pod husk meal was terminated on the $14^{\text {th }}$ day followed by sun drying of the substrates for $5-7$ days to inactivate the microorganisms. The dried CPH meal was subsequently kept in air-tight plastic container while a sample was taken for post-fermentation proximate analysis.

\section{Experimental Animals and Arrangement}

Sixty 5 weeks ( 35 days) old grower rabbits comprising thirty New Zealand White breed and thirty Chinchilla breed were purchased from a reputable farm in Ogun State, weighed individually and grouped into treatments after balancing for weights and penned individually in their hutches using completely randomized design for eight experimental weeks. There were ten replicates per treatment with one rabbit per replicate. Weekly weights and feed intake of each rabbit were measured.

\section{Experimental Diets}

Three experimental diets were formulated to meet the nutritional requirements of the grower rabbits in which fermented cocoa pod husk meal (FCPHM) was incorporated into the feed as the test ingredient at varied levels of 0.0 , 12.5 and $25.0 \%$ which were designated as Diet I (control), Diet II and Diet III respectively. The animals were provided feed and water ad libitum throughout the eight-week experimental period. The gross composition of the experimental diets for the rabbits is presented in Table 1. 
Table 1: Gross composition of the experimental diets for rabbits.

\begin{tabular}{|c|c|c|c|}
\hline \multirow[t]{2}{*}{ Ingredients } & Diet I & Diet II & Diet III \\
\hline & $0.0 \%$ & $12.5 \%$ & $25.0 \%$ \\
\hline Maize & 18.40 & 21.10 & 19.40 \\
\hline GNC & 8.70 & 7.80 & 4.60 \\
\hline $\mathrm{PKC}$ & 25.50 & 10.80 & 7.40 \\
\hline SBM & 4.50 & 4.30 & 3.10 \\
\hline Wheat offal & 6.90 & 3.40 & 0.40 \\
\hline GNH & 34.20 & 38.50 & 38.50 \\
\hline FCPH & 0.00 & 12.50 & 25.00 \\
\hline Vegetable Oil & 0.80 & 0.80 & 1.10 \\
\hline Lysine & 0.10 & 0.10 & 0.10 \\
\hline Methionine & 0.10 & 0.10 & 0.10 \\
\hline Limestone & 0.40 & 0.30 & 0.10 \\
\hline Premix & 0.20 & 0.15 & 0.10 \\
\hline Salt & 0.20 & 0.15 & 0.10 \\
\hline Total & 100.00 & 100.00 & 100.00 \\
\hline \multicolumn{4}{|l|}{ Calculated Composition } \\
\hline Dry Matter, DM (\%) & 90.15 & 89.87 & 89.29 \\
\hline Metabolisable Energy, ME (Kcal/kg) & 2505.89 & 2506.44 & 2501.95 \\
\hline Crude Protein, CP (\%) & 15.92 & 15.95 & 15.68 \\
\hline Crude Fiber, CF (\%) & 15.64 & 15.05 & 15.04 \\
\hline Calcium, $\mathrm{Ca}(\%)$ & 0.94 & 0.93 & 0.82 \\
\hline Av. Phosphorus, P (\%) & 0.69 & 0.64 & 0.59 \\
\hline Lysine (\%) & 0.87 & 0.88 & 0.79 \\
\hline Methionine (\%) & 0.60 & 0.59 & 0.59 \\
\hline \multicolumn{4}{|l|}{ Analysed Composition } \\
\hline Dry Matter, DM (\%) & 88.30 & 88.90 & 87.86 \\
\hline Crude Protein, CP (\%) & 16.38 & 16.47 & 16.01 \\
\hline Crude Fiber, CF (\%) & 15.62 & 15.07 & 14.95 \\
\hline Ash $(\%)$ & 4.51 & 7.33 & 7.18 \\
\hline Ether Extract (\%) & 6.32 & 5.14 & 5.06 \\
\hline Nitrogen-Free Extracts (\%) & 45.47 & 44.89 & 44.66 \\
\hline
\end{tabular}




\section{Sample Collection}

Two rabbits were taken from each dietary treatment groupand humanely slaughtered. The animals were dissected and the gastrointestinal tract was located, then was removed. Samples of the caecal content for microbial analysis were collected in a sterile manner from approximately $3 \mathrm{~cm}$ from the ileocaecal junction. The following analysis were carried out on the samples collected.

\section{Microbiological Analysis}

\section{Bacterial isolation and determination of total viable counts}

A portion of each sample (1g) taken from the caecum of experimental rabbits was added into test tubes containing sterile distilled water $(9 \mathrm{ml})$ and was thoroughly mixed to serve as stock. Four fold serial dilutions $\left(10^{-1}\right.$ to $\left.10^{40}\right)$ of the stock was done using $1 \mathrm{ml}$ stock homogenate and $9 \mathrm{mls}$ sterile distilled water in order to obtain discrete colonies (Moshoodet al., 2012). The media (Nutrient Agar) used was prepared from commercially dehydrated products and reconstituted according to the manufacturer's directives, sterilized and allowed to cool. $1 \mathrm{ml}$ each of the serially diluted sample was dropped at the centre of a Petri-dish followed by pouring of the nutrient agar using the pour plate method as described by Mumtazet al. (1986). It was allowed to solidify for some minutes and then incubated at $37{ }^{\circ} \mathrm{C}$ for

Table 2: Bacterial and Coliform counts isolated from caecum of New Zealand White and Chinchilla rabbits fed diets containing

\section{FCPHM}

\begin{tabular}{|c|c|c|c|}
\hline \multicolumn{2}{|c|}{ Factors } & \multirow{2}{*}{$\begin{array}{c}\begin{array}{c}\text { Total Bacterial Count } \\
\left(\times \mathbf{1 0}^{\mathbf{2}} \mathbf{c f u} / \mathbf{m l}\right)\end{array} \\
93.67^{\mathrm{a}}\end{array}$} & \multirow{2}{*}{$\begin{array}{c}\begin{array}{c}\text { Total Coliform Count } \\
\left(\times \mathbf{1 0}^{2} \mathbf{c f u} / \mathbf{m l}\right)\end{array} \\
13.58^{\mathrm{a}}\end{array}$} \\
\hline Breed & NZW & & \\
\hline & CHL & $70.58^{\mathrm{b}}$ & $8.56^{\mathrm{b}}$ \\
\hline & SEM & 7.18 & 1.15 \\
\hline & P-value & 0.036 & 0.006 \\
\hline FСРНМ & Control & $56.88^{\mathrm{b}}$ & $7.38^{\mathrm{b}}$ \\
\hline \multirow[t]{4}{*}{ Inclusion levels } & $12.5 \%$ & $87.82^{\mathrm{a}}$ & $10.63^{\mathrm{b}}$ \\
\hline & $25 \%$ & $101.63^{\mathrm{a}}$ & $15.25^{\mathrm{a}}$ \\
\hline & SEM & 8.80 & 1.41 \\
\hline & P-value & 0.006 & 0.003 \\
\hline \multicolumn{4}{|c|}{ Interaction Effect (Breed X FCPHM Inclusion Level) } \\
\hline \multirow[t]{3}{*}{ NZW } & Control & 55.25 & 9.25 \\
\hline & $12.5 \%$ & 101.25 & 15.50 \\
\hline & $25 \%$ & 124.50 & 16.00 \\
\hline CHL & Control & 58.50 & 5.50 \\
\hline
\end{tabular}




\begin{tabular}{ccc}
$12.5 \%$ & 74.50 & 5.75 \\
$25 \%$ & 78.75 & 14.50 \\
SEM & 12.44 & 1.99 \\
P-value & 0.168 & 0.129 \\
\hline
\end{tabular}

CHL=Chinchilla; NZW=New Zealand White, FCPHM=Fermented Cocoa Pod Husk Meal; cfu = Colony formed unit.

\section{RESULTS}

\section{Bacterial and Coliform Counts}

Tables 2 shows the total viable bacterial and coliform counts obtained from samples in the ceacum of the New Zealand White and Chinchilla rabbits fed the different experimental diets. It revealed that the breed effect had significant $(\mathrm{P}<0.05)$ influence on the bacteria and coliform $(\mathrm{P}<0.01)$ counts. The chinchilla rabbit had fewer bacterial $(70.58 \times$ $\left.10^{2} \mathrm{cfu} / \mathrm{mi}\right)$ and coliform $\left(8.58 \times 10^{2} \mathrm{cfu} / \mathrm{ml}\right)$ counts than the New Zealand White rabbits. The dietary inclusions of FCPHM also had significant effect $(\mathrm{P}<0.05)$ on the bacterial and coliform counts and the least count was recorded in the control group $\left(56.88 \times 10^{2} \mathrm{cfu} / \mathrm{ml}\right)$ followed by the group fed diet containing $12.5 \%$ FCPHM $(87.88 \times 102 \mathrm{cfu} / \mathrm{ml})$ and then the $25 \%$ FCPHM group $\left(101 \times 10^{2} \mathrm{cfu} / \mathrm{ml}\right)$. The interaction effect between the breed and varying dietary treatment factors had no significant effect $(\mathrm{P}>0.05)$ on both bacterial and coliform counts.

\section{Percentage distribution of bacteria organisms isolated from caecum of experimental rabbits}

The varying diets significantly $(\mathrm{P}<0.05)$ affected the abundance and richness of certain types of bacteria detected in the experimental rabbits.

Detailed percentages of the bacteria organisms isolated from the caecum of the Chinchilla rabbits fed the different levels of dietary FCPHM is shown in Figures 1A-C. OnlySalmonella spp. and Bacillus cereus were commonly isolated from the rabbits fed the three dietary treatments while Aerobacter cloacae, Enterobacter sppand Klebsiellasppwere further isolated from the control group; Aerobacter cloacae, Enterobacter spp and Bacillus subtilis were isolated from the $12.5 \%$ FCPHM group whileStreptococcus faecalis, Proteus spp, Bacillus subtilis and Klebsiellaspp were further isolated from the $25 \%$ FCPHM group.

Figures 2A-Cshows that Klebsiellaspp, Salmonella typhi and Bacillus cereus were present in the caecum of the New Zealand White rabbits in all the treatment groups. Staphylococcus epidermidis, Enterobacter spp and Bacillus subtilis were also found in rabbits fed the control diet and the $12.5 \%$ FCPHM supplemented diet whileProteus spp and Staphylococcus epidermidis were further isolated from those fed 25\%FCPHM supplemented diet.

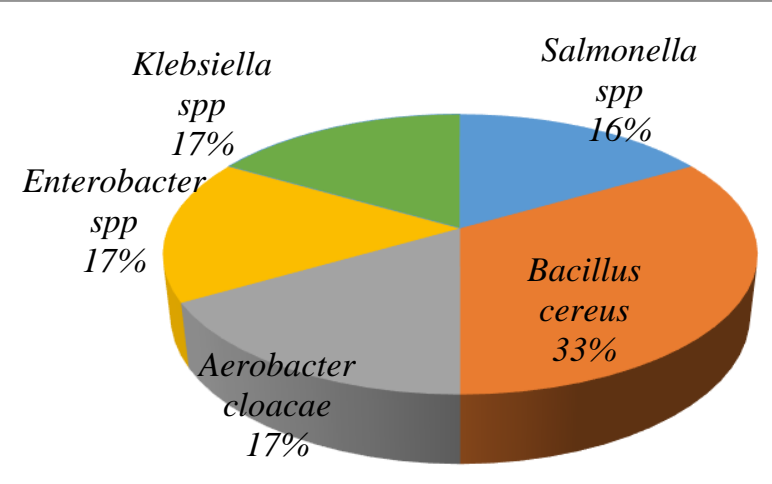

Fig. 1A : Percentage distribution of bacteria isolated from caecum of Chinchilla rabbits fed with control diet 

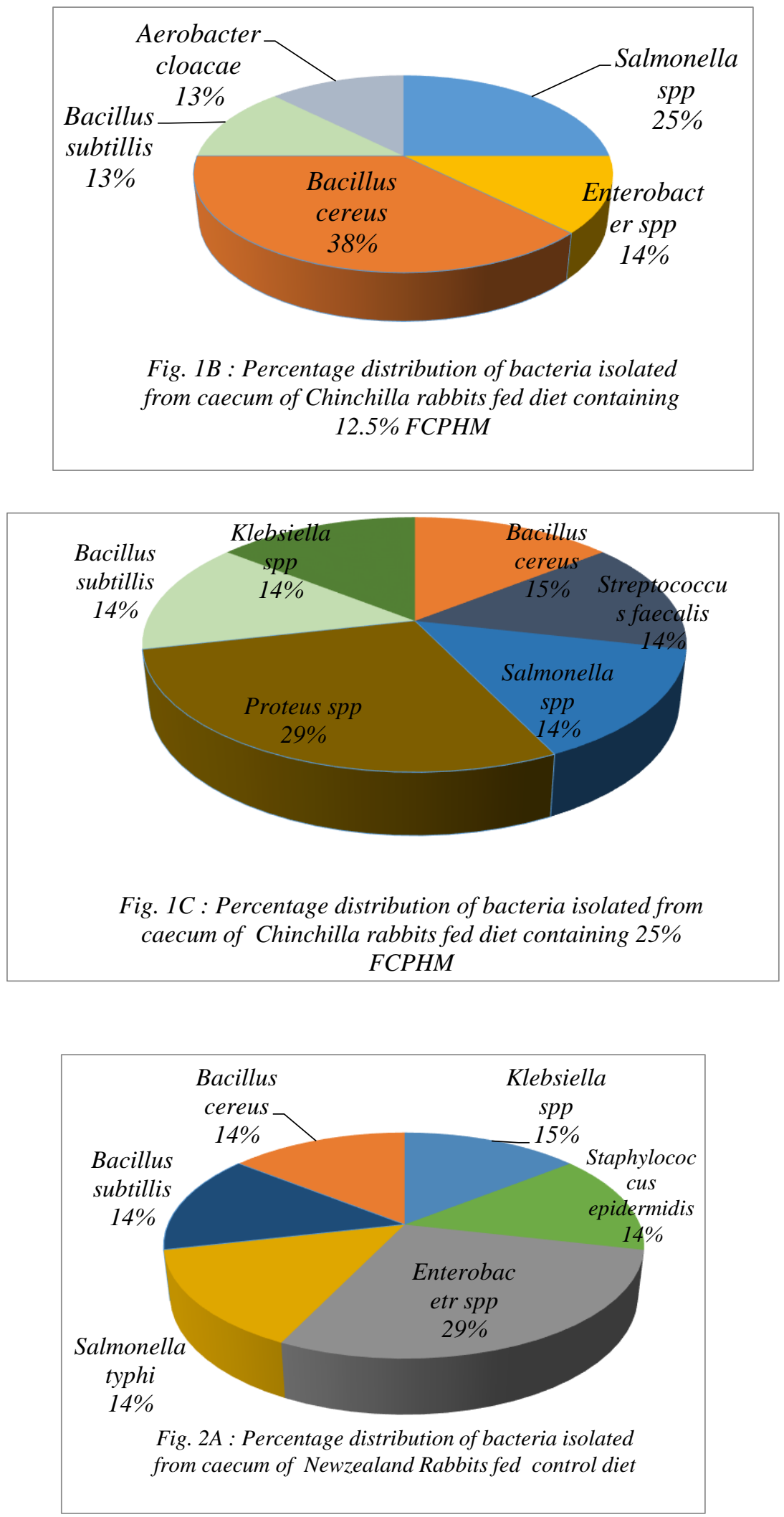


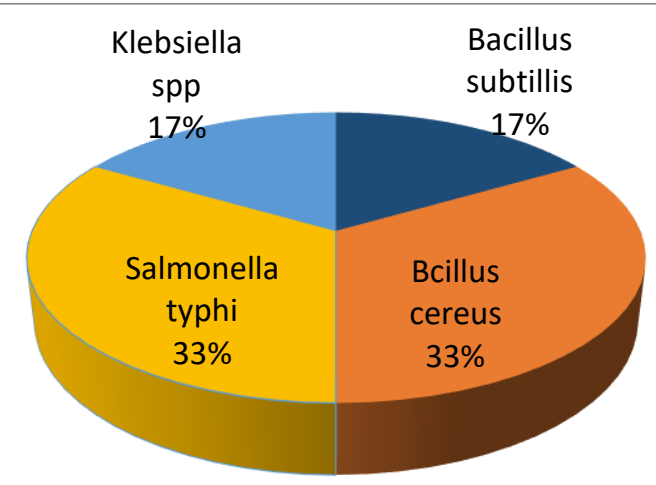

Fig. 2B : Percentage distribution of bacteria isolated from caecum of Newzealand Rabbits fed diet containing $12.5 \%$ FCPHM

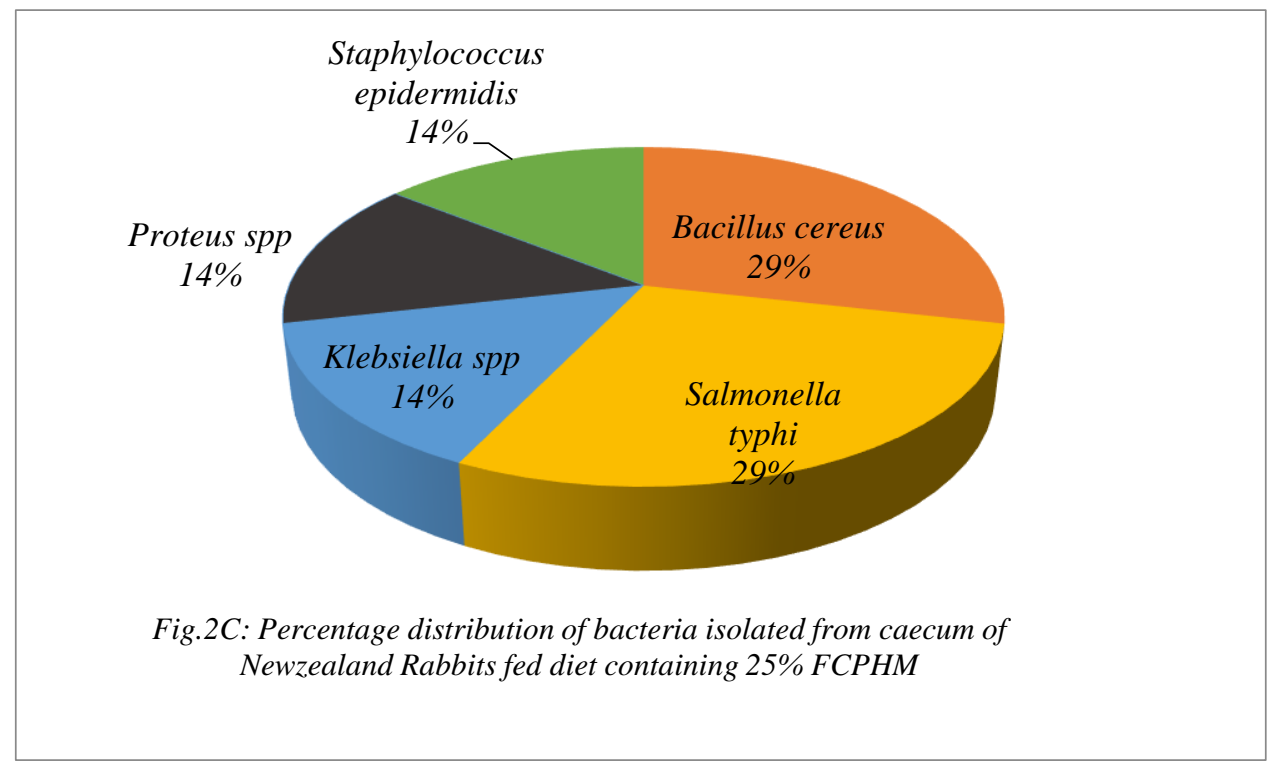

\section{DISCUSSION}

The rabbit enteric microbiota plays a key role in maintaining rabbit health, including helping to digest forage-based diet and aiding in immune system regulation and development (Kylie, 2016).

This present study revealed the presence of a wide variety of bacteria in the caecum of the experimental rabbits.Earlier speculationhas been made that rabbit caeca contain a large proportion of undescribed bacterial species (Michellandet al., 2010) and this suggested that the composition of these novel species may vary between individuals which was further buttressed by the report of North et al. (2019).In this study for the overall bacterial communities, the bulk of the bacterial population across breeds and diets were observed to be Bacillus, Salmonella,Klebsiella, Enterobacter, Staphyloccusspp, Aerobacterand Proteus. However, a high percentage of reads across samples were assigned to Bacillus species and Salmonella organisms which suggests that the richness of certain bacteria was significantly affected by diet as opined by Zhu et al. (2015).

It was noted that the bacteria Lactobacillus genus was not isolated from the gut of experimental rabbits which is in line with report by Fortun-Lamothe and Boullier (2004) that the absence of the genus Lactobacillus in the rabbit flora is original. Also Zhu et al. (2015) reiterated the absence of the genus Lactobacillus in the rabbit flora as unique and being in accordance with previous data obtained by $\mathrm{Yu}$ and Tsen (1993) with culture-based methods. Penney et al. (1986) previously hypothesized that this is due to highly acidic environment in the GIT of adult rabbits.

Also, this present study revealed the absence of Escherichia coli in the gut of adult rabbits and this is similar to reports of 
large-scale studies that the cultivable fraction of rabbit digestive microbiota in healthy adults is characterizedby the absence or low density of Escherichiacoli (Yu andTsen 1993; Pupoet al. 1997). Fortun-Lamothe and Boullier (2004) also made similar observations that Escherichia coli reached a maximum level at the 2 nd or 3 rd week of life and then decreased to be residualor absent after weaning in the gut of rabbits.

It was further discovered in this present study that the microbial abundance varied with the different nutritional treatments and breeds of rabbits. This may be due to the fact that an important fraction of the diets enters the caecumas substrates for microbial fermentation and a change indiet composition can modify the nature of the digestato be fermented in the caecum and, consequently, canaffect microbiota composition and activity as suggested by Jehl andGidenne(1996). Previously, a study by BogoneVantuset al. (2014) reported that microbes present in the gastrointestinal tract are a direct function of the nutrition of the rabbits. This suggests that the FCPHM inclusion in the diets of the experimental rabbits aided the proliferation of different types of bacteria organisms. This is further buttressed by the work of Michellandet al. (2011) which demonstrated that the bacterial communities of therabbit caecum change and adapt rapidly to reach a newequilibrium in response to nutrition.However, in a particular study, the impact of dietary composition on gut microbiota was not reported (Massipet al. 2012).

Also, in line with this present study where a variety of bacterial organisms was found in the caecum of the experimental rabbits, Combes et al. (2013) asserted that an abundant bacterial community is present throughout the caecum-colon and in the hard and soft faeces $\left(10^{10}-10^{12}\right.$ bacteria/bag) of rabbits.

The diverse and abundant bacterial population reported in the caecum of experimental rabbits probably as a result of inclusion of FCPHM in diet at varying levels may influence their general performance and health. This is because studies havesuggested that the composition and the activity of the caecal microbiota could have a strong influence on health, because of its role in nutrition, pathogenesis and immune function as manifested by hydrolysis of plant fibers and cell walls by bacterial enzymes, which is not possible by host animal digestive enzymes as opined by Gibson and Roberfroid (1995).

The effect of breed significantly influenced the total counts of bacteria isolated from the experimental rabbits. The effect of the varying dietary treatments were also pronounced on the bacterial and coliform counts whereas the combined effects of breed and dietary treatments were not pronounced on the bacterial and coliform counts.

The bacteria and coliform counts in caecum of New Zealand White rabbits were found to be more than that of Chinchilla rabbits which can be attributed to breed effect, while the rabbits fed with varying levels of FCPHM were found to have higher counts of bacteria compared with those fed the control diet without FCPHM. The result also showed that the higher the level of inclusion of FCPHM the higher the bacteria and coliform counts recorded. This may be as a result of the highfibre content in the diet with the highestinclusion level of FCPH meal which is in line with reports of previous studies that in animals fed a high-fiber diet, bacteria were found in the highest abundance compared with animals fed diets with lower fiber content (Gidenne and Bellier 2000; Gidenne and Fortun-Lamothe 2002). Similarly, Gidenneet al. (2004) suggested that the total bacterial biomass production was 3 -fold higher for rabbits fed a high fiber/starch ratio. Though, Zhu et al. (2015) suggested that an unbalanced diet withexcessive fiber or starch reduces microbial richness and diversity. Earlier studies had also reported that dietary starch/fibre was long thought to be a factor that predisposed rabbits to the development of undesirable microbiota (Cheeke and Patton. 1980).

The low coliform bacteria counts relative to the total bacteria counts ratio in the FCPH meal fed rabbits suggested that the caecum was predominantly colonized by non-pathogenic bacteria and toxic substances of pathogens were inhibited by gut beneficial bacteria as earlier hypothesized by Phuoc and Jamikorn (2017). It may also be due to the fact that acetic acid produced by resident bacteriaduring fermentation process is able to penetrate into bacterial cytoplasm resulting in a reduced internal bacterial $\mathrm{pH}$ and collapse of the electrochemical proton gradient which leads to bacteriostasis and death of susceptible bacteria such as caecal coliforms (Eklund, 1989).

Overall, this large bacterial community in the gut influences the overall health status of the rabbits as well as imparts on the digestion process in the animals. This is ascertainedbecause short-chain fatty acids (acetate, butyrate, and propionate) which are metabolic end products from bacteria such as those present in the gut of the experimental rabbits are pivotal in several host physiological functions, such as nutrient acquisition, immunity, cell signalling, proliferation control, and pathogen protection as reported earlier by Tremaroli and Bäckhed(2012). 


\section{CONCLUSION}

The inclusion of fermented cocoa pod husk meal (FCPHM) in feed of New Zealand and Chinchilla breeds of rabbit enhanced number of gut beneficial bacteria populations which could improve caecal fermentation and ultimately lead to better gut health and growth performance. In addition, caecal coliform population were reduced in the experimental rabbits. Also, the varying diets caused the proliferation of different types of bacteria in the gut.

\section{REFERENCES}

[1] Adegbola, J. A., E.U. Tibi and D.C. Adogwa, 1985. Feed intake and digestibility in Rabbits fed all forage plus concentrate and all concentrate diet. Journal of Animal Production Research, 5(2): 15-16.

[2] Ajayi, A.F., O.G. Farinu, O.O. Ojebiyi and T.B. Olayeni, 2007. Performance evaluation of male weaner rabbits fed diets containing graded levels of blood-wild sunflower leaf meal mixture. World Journal of Agricultural Science, 3(2): 250-255

[3] Bagóné, V., M. Vántus, A. Kovács and Z. Solnai, 2014. The rabbit caecal microbiota: development, composition and its role in the prevention of digestive diseases; A review: On recent literature in the light of molecular genetic methods.Kaposvár University, Faculty of Agriculturaland Environmental Sciences, 18 (1): 55-65.

[4] Cheeke, P.R. and N.M. Patton, 1980. Carbohydrate overload of the hindgut. A probable cause of enteritis. Journal of Applied Rabbit Research,3(3): 20-23.

[5] Combes, S., L. Fortun-Lamothe, L. Cauquil and T. Gidenne, 2013. Engineering the rabbit digestive ecosystem to improve digestive health and efficacy. Animal, 7: 1429-1439. https://doi.org/10.1017/S1751731113001079

[6] Conlon, M.A. and A.R. Bird, 2014. The impact of diet and lifestyle on gut microbiota and human health. Nutrients, 7:17-44. https://doi.org/10.3390/nu7010017 PMID: 25545101

[7] Eklund, T.,1989.Organic acids and esters. In: Gould GW, editors. Mechanisms of action of food preservation procedures. NY: Elsevier; p. 161-200.

[8] Esonu, B.O., J.C. Azubuike, O.O. Emenalom, E.B. Etuk, I.C. Okoli, H. Ukwu and C.S. Nneji 2004. Effect of Enzyme Supplementation on the performance of Broiler finisher fed microdesmispeberula leaf meal. International Journal of Poultry Science, 3(2): 112-114

[9] Fawole, M.O. and B.A. Oso, 2001. Laboratory Manual of Microbiology. Revised Edition, Spectrum Books, Ibadan.

[10] Fortun-lamothe L. and S. Boullier, 2004. Interactions between gut microflora and digestive mucosal immunity and strategies to improve digestive health in young Rabbits.
Proceedings - 8th World Rabbit Congress - September 7-10, 2004 - Puebla, Mexico, Invited Paper.

[11] Gibson, G. and M. Roberfroid, 1995. Dietary modulation of the human colonic microbiota: introducing the concept of prebiotics. Journal of Nutrition, 125: 1401-1412. PMID:7782892.

[12] Gidenne, T. and R. Bellier, 2000. Use of digestible fibre in replacement to available carbohydrates-Effect on digestion, rate of passage and caecal fermentation pattern during the growth of the rabbit. Livestock Production Science 63, 141152.

[13] Gidenne, T., and L. Fortun-Lamothe, 2002. Feeding strategy for young rabbits around weaning: a review of digestive capacity and nutritional needs. Animal Science, 75: 169-184.

[14] Gidenne, T., N. Jehl, A. Lapanouse and M. Segura, 2004. Interrelationship of microbial activity, digestion and gut health inthe rabbit: effect of substituting fibre by starch in diets having a high proportion of rapidly fermentable polysaccharides. British Journal Nutrition, 92(1): 95-104. doi:10.1079/BJN20041173. PMID:15230992.

[15] Gidenne, T., A. Lapanouse and L. Fortun-Lamothe, 2004. Feeding strategy for the early weaned rabbit: interest of a high energy and protein starter diet on growth and health status, In: Becerril, C. and Pro, A. (ed.). Proceedings of the 8th World Rabbit Congress, Puebla, Mexico, 7-10 September, Colegio de Postgraduados for WRSA publ., pp 853-860 (http://world-rabbit-science.com/).

[16] Janieri, A. 2003. Nutritional quality of rabbit meat. Italian R.V. Agriculture, 24: 275.

[17] Jehl, N. and T. Gidenne. 1996. Replacement of starch by digestible fibre in feed for the growing rabbit. 2 . Consequences for microbial activity in the caecum and on incidence of digestive disorders. Animal Feed Science Technology. 61(1): 193-204. doi:10.1016/03778401(95)00938- 8.

[18] Kim, J.E., H.S. Lillehoj, Y.H. Hong, G.B. Kim, S.H. Lee, E.P. Lillehoj, 2015. Dietary Capsicum and Curcuma longa oleoresins increase intestinal microbiome and necrotic enteritis in three commercial broiler breeds. Research Veterinary Science, 102:150-158. https://doi.org/10.1016/j.rvsc.2015.07.022 PMID: 26412535

[19] Kylie, J. 2016.An Investigation into the Fecal Microbiota of Domestic Rabbits (Oryctolaguscuniculus) and factors influencing its composition. A thesis presented to the University of Guelph, Ontario, Canada in partial fulfilment of requirements for the degree of Doctor of Veterinary Science.

[20] Makinde, O.J., S.A. Okunade, E. Opoola, A.B. Sikiru, S.O. Ajide and S. Elaigwu, 2019. Exploration of Cocoa (Theobroma cacao) By-products as valuable potential resources in feeds and feeding systems. A chapter in a bookDeploying science for sustainability of global cocoa economy. DOI:10.5772/intechopen.87871. https:/www.intechopen.com/books. 
[21] Massip, K., S. Combes, L. Cauquil, O. Zemb and T. Gidenne, 2012. High throughput 16S-DNA sequencing for phylogenetic affiliation of the caecal bacterial community in the rabbit: Impact of the hygiene of housing and of the intake level. In Proc.: 8th INRA-RRI Symposium on Gut Microbiology, 18-21 June, 2012. Clermont-Ferrand, France. 1: 57.

[22] Michelland, R.J., S. Combes, V. Monteils, L. Cauquil, T. Gidenne and L. Fortun-Lamothe, 2010. Molecular analysis of the bacterial community in digestive tract of rabbit. Anaerobe, 16: 61-65. https://doi.org/10.1016/j.anaerobe.2009.05.002

[23] Michelland, R., S. Combes, V. Monteils, L. Cauquil, T. Gidenne and L. Fortun-Lamothe, 2011. Rapid adaptation of the bacterial community in the growing rabbit cæcum after a change of dietary fibre supply. Animal, 5(11): 1761-1768. doi:10.1017/S1751731111001005. PMID:22440416.

[24] Moshood, A.Y., H.A. Tengku and H. Ibrahim, 2012. Isolation and identification of bacteria (roasted meat products) sold in Bauchi, Nigeria. IOSR, Journal of Pharmacy, 2(6): 38-48.

[25] Mumtaz, B., A. Zafar and B. Abdul, 1986. Quantitative and qualitative microbial load determination from meat samples effected by time and temperature. Journal of Pakistan Medical Association. pp. 90-93.

[26] North, M.K., A. DalleZotte and L.C. Hoffman, 2019. Composition of rabbit caecal microbiota and the effects of dietary Quercetin supplementation and sex thereupon. World Rabbit Science, 27:185-198.

[27] Oduguwa, O.O., A.O. Fanimo and A.V. Agbede, 2004. Effect of enzymes supplementation on the utilization of shrimp waste meal based diets by broiler chicken. Nigeria Journal of Animal Production .31(2): 168-172.

[28] Olutiola, P.O., O. Famurewa,H.G. Sonntag, 1999. An introduction to microbiology; A practical approach. HeildebergerVerlagsanstalt and Drukkerei GMBH, Germany. 157-180.

[29] Oseni, S.O., B.A., Ajayi, S.O., Komolafe, O. Siyanbola, M. Ishola and G. Madamidola, 2008. Smallholder rabbit production in Southwestern Nigeria: current status, emerging issues and ways forward. 9th world rabbit congress, June 1013, 2008, Verona, Italy.

[30] Ozor, N. and M.C. Madukwe, 2005. Obstacles to the adoption of improved rabbit technologies by small scale farmers in Nsukka Local Government Area of Enugu State. Journal of Agriculture, Food, Environment and Extension, 4(1): 70-73.

[31] Penney, R.L., G.E. Folk Jr, R.P. Galask, C.R. Petzold, 1986. The microflora of the alimentary tract of rabbit in relation to $\mathrm{pH}$, diet and cold. Journal of Applied Rabbit Research, 9:152-156.

[32] Phuoc, T.L. and U. Jamikorn, 2017.Effects of probiotic supplement (Bacillus subtilis and Lactobacillus acidophilus) on feed efficiency, growth performance, and microbial population of weaning rabbits. Asian-Australas Journal of Animal Science, 30(2):198-205.

[33] Rukayya, H.M., J.A. Zainab, A.Y. Clement, B.B. Musa and M.R. Adedaya, 2016. Assessment of Bacteria associated with ready-to-eat food sold at Federal University of Dutse, JigawaState. Nigeria International Journal of Current Research in Bioscience and Plant Biology, 3(4): 5-14.

[34] Tremaroli, V. and F. Bäckhed, 2012. Functional interactions between the gut microbiota and host metabolism. Nature, 489(7415): 242-249. doi:10.1038/nature11552. PMID:22972297.

[35] Yu, B. and H.Y. Tsen, 1993. Lactobacillus cells in the rabbit digestive tract and factors affecting their distribution. Journal of Applied Bacteriology, 75(3): 269-275. doi:10.1111/j.13652672.1993.tb02776.x.PMID:8244905.

[36] Zhu, Y., C. Wang, F. Li, 2015. Impact of dietary fiber/starch ratio in shaping caecal microbiota in rabbits. Canadian Journal of Microbiology, 61: 771-784. https://doi.org/10.1139/cjm-2015-0201 